\title{
CASE REPORT: LABIAL VENEER ALL PORCELAIN WITH PRESS METHOD FOR IMPROVING AESTHETIC ON PATIENT WITH CENTRAL DIASTEMA CASE
}

\author{
Endang Prawesthi, Moh Hasan \\ Jurusan Teknik Gigi, Politeknik Kesehatan Kemenkes RI Jakarta II \\ Jl. Hang Jebat III/ F3 Kebayoran Baru Jakarta, Indonesia \\ E-mail: endangprawesthi@yahoo.com
}

\begin{abstract}
Patients with central diastema disorders often feel shame and less 0f confident. The disorder can be repaired by a Labial veneer restoration. This restoration is an improvement in the form of a layer on the labial surface of the tooth selected because it gives satisfactory aesthetic results and maintains the tooth structure. At this time, the method of fabricating labial veneer all porcelain growing rapidly, such as making labial veneer all porcelain with base layer using press method like all porcelain E-max press. This paper aims to determine the stages and problem solving of the difficulties that arise in the procedure of fabricating labial veneer all porcelain with the basic layer of labial veneer using press method. The method is based on working model done in dental laboratory, starting from work model preparation, wax contouring (wax up), Sprueing, Investing, Preheating, Pressing, Divesting, Cutting sprue and Build-up porcelain. Results obtained from making this labial veneer all porcelain is a tightly closed diastema that forms a contact of the field, smooth and glossy surface and good aesthetic.
\end{abstract}

Keywords: Labial veneer, All Porcelain, Central Diastema

\section{LAPORAN KASUS: LABIAL VENEER ALL PORCELAIN DENGAN METODE PRESS UNTUK MEMPERBAIKI ESTETIK PADA PASIEN DENGAN KASUS DIASTEMA SENTRAL}

\begin{abstract}
ABSTRAK
Pasien dengan kelainan diatema sentral seringkali merasakan malu dan percaya diri yang kurang.. Kelainan tersebut dapat diperbaiki dengan suatu restorasi Labial veneer. Restorasi ini merupakan perbaikan berupa suatu lapisan pada permukaan labial gigi yang dipilih karena memberikan hasil estetika yang memuaskan dan mempertahankan struktur gigi. Saat ini metode pembuatan labial veneer all porcelain berkembang dengan pesat, diantaranya adalah pembuatan labial veneer all porcelain dengan lapisan dasar menggunakan metode press seperti all porcelain Emax press. Makalah ini bertujuan untuk mengetahui tahapan serta pemecahan masalah dari kesulitan yang timbul pada prosedur pembuatan labial veneer all porcelain dengan lapisan dasar labial veneer menggunakan metode press. Metodenya berdasarkan model kerja yang dikerjakan di laboratorium gigi, dimulai dari persiapan model kerja, Counturing wax (wax up), Sprueing, Investing, Preheating, Pressing, Divesting, Cutting sprue dan Build-up porcelain. Hasil yang didapat dari pembuatan labial veneer all porcelain ini adalah Diastema tertutup rapat sehingga membentuk kontak bidang, permukaan halus dan mengkilap serta estetika baik.
\end{abstract}

Kata Kunci : Labial veneer, All Porcelain, Diastema Sentral 


\section{PENDAHULUAN}

Penampilan merupakan sesuatu hal yang penting, senyuman yang indah dengan deretan gigi yang rapih dan lengkap merupakan salah satu dambaan setiap orang. Gigi anterior sangat berperan penting dalam menunjang penampilan seseorang. Kelainan atau kerusakan gigi merupakan hal yang sering terjadi karena kurangnya kesadaran masyarakat akan pentingnya peranan serta perawatan gigi. Jika terdapat kelainan atau kerusakan pada gigi anterior akan sangat mengganggu penampilan. Salah satu kelainan pada gigi anterior yaitu terdapatnya diastema central yang berdampak pada estetik dan kepercayaan diri seseorang. Diastema adalah suatu ruang dengan ukuran lebih dari $0.5 \mathrm{~mm}$ antara permukaan proksimal gigi dengan gigi sebelahnya. Seringkali diastema ini menyebabkan gangguan estetik bagi sebagian orang, terutama diastema yang terdapat di anterior. Adanya ruang antara dua gigi yaitu gigi incisivus 1 pada rahang atas yang berdekatan dikenal dengan diastema central. Oleh karena itu, bagi sebagian orang diastema central ini merupakan suatu gangguan estetik terhadap penampilannya. $(1,2)$

Banyak cara untuk mengatasi diastema central, baik perawatan ortodonsi, restorasi labial veneer, mahkota, atau tumpatan resin komposit.(3) Labial veneer merupakan pilihan yang baik dengan memberikan hasil estetika memuaskan dan dapat mempertahankan struktur gigi serta dapat digunakan secara luas untuk memperbaiki estetika pada gigi yang mengalami perubahan warna dan kerusakan pada struktur gigi. (4) Saat ini metode pembuatan labial veneer all porcelain juga berkembang dengan pesat, diantaranya adalah pembuatan labial veneer all porcelain anterior dengan metode press seperti all porcelain E-max press.

All porcelain tipe E-max press adalah bahan porcelain berupa ingot lithium disilicate glass-ceramic highly aesthetic, memberikan homogenitas yang optimal dan memiliki kekuatan tinggi untuk pembuatan restorasi cekat yang akurat. E-max press tersedia dalam 4 level translusensi dan 2 ukuran, yaitu HT (high translucency), LT (low translucency), MO (medium opacity), dan HO (high 2 opacity). Dari sudut pandang pembuatannya, pada dasarnya semua restorasi dapat dibuat dari ingot apapun. Untuk alasan estetika, maka teknik pembuatan dan indikasi dapat direkomendasi untuk setiap ingot pada tingkat translusensi. Metode yang digunakan dalam pembuatan labial veneer all porcelain dengan bahan E-max press yaitu menggunakan bahan porcelain khusus yang di lelehkan dan dipress ke dalam mould space menggunakan mesin furnace khusus. (5)

Pada makalah ini akan dibahas mengenai pembuatan labial veneer all porcelain dengan lapisan dasar menggunakan metode press pada kasus diastema sentral rahang atas. Karena, seiring dengan berkembangnya ilmu pengetahuan khususnya di bidang gigi tiruan cekat, maka teknisi gigi dituntut untuk meningkatkan ketrampilan dan keahliannya dalam pembuatan restorasi yang bermanfaat bagi masyarakat, khususnya untuk memperbaiki atau mengkoreksi kelainan yang ada pada pasien dengan kasus diastema central.

\section{Diastema}

Diastema adalah suatu ruang lebih dari $0.5 \mathrm{~mm}$ antara permukaan proksimal dengan gigi sebelahnya. Seringkali diastema ini menyebabkan gangguan estetik bagi sebagian orang, terutama diastema yang 
terdapat di anterior. Adanya ruang antara dua gigi yaitu gigi incisivus pada rahang

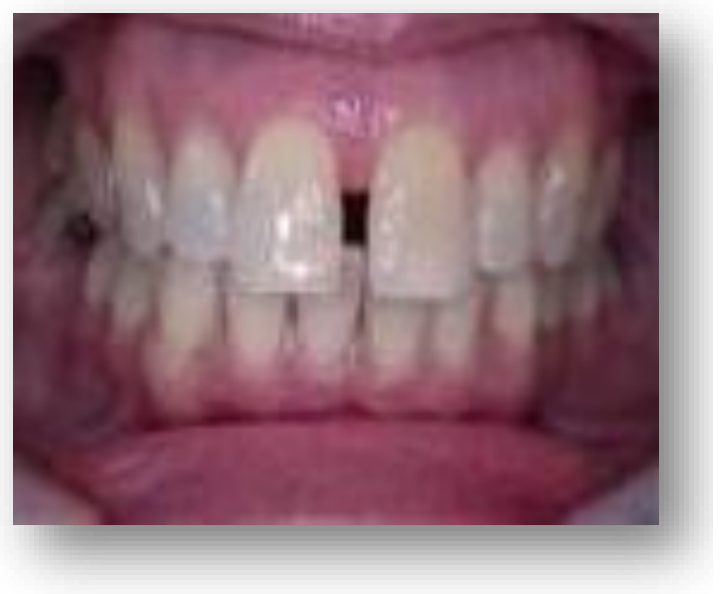

Gambar 1. Diastema Central

atas yang berdekatan dikenal dengan diastema sentral. $(1,2)$

Diastema sentral (Gambar 1) pada umumnya disebabkan oleh beberapa hal, yaitu ukuran gigi incisivus normal atau lebih kecil tetapi ukuran lengkung rahang melebihi normal, Anomali gigi incisivus (microdontia), Perlekatan frenulum yang abnormal, Kebiasaan buruk menghisap ibu jari dan menjulurkan lidah, Gigi sepernumerary di median line, Kehilangan gigi incisivus lateral secara congenital, Rotasi gigi incisivus. Ada beberapa cara untuk mengatasi diastema sentral, antara lain yaitu perawatan orthodontic, Labial veneer, Jacket crown, restorasi resin komposit. (3)

\section{Labial Veneer}

Labial veneer (Gambar 2) adalah suatu restorasi yang sewarna dengan gigi dan diaplikasikan pada permukaan labial gigi yang mengalami perubahan warna juga kerusakan pada struktur gigi untuk memperbaiki estetika. Karena labial veneer merupakan lapisan tipis pada permukaan

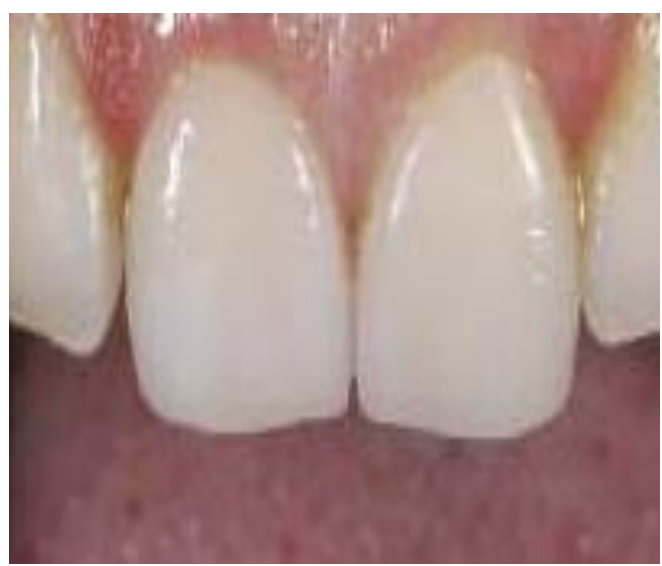

Gambar 2. Labial Veneer

labial, mencari kesesuaian warna yang sempurna dari lapisan porcelain ini agak sulit. (4-6)

Indikasi pemakaian labial veneer, yaitu: Karies, gigi malformasi. Perubahan warna gigi karena devitalisasi, Perubahan warna gigi karena obat-obatan, Perubahan warna karena faktor usia, Gigi diastema, Adanya bercak putih pada gigi, Mahkota gigi yang patah akibat trauma, Perawatan prostetik untuk gigi tetap pada pasien muda. Sedangkan Kontra indikasi labial veneer yaitu Pasien memiliki tingkat karies yang tinggi, Resesi gingival, Gigi yang mengalami rotasi yang berlebihan, Bruxism dan Pasien dengan penyakit periodontal yang parah. $(6,7)$

Labial veneer memiliki fungsi untuk memperbaiki estetik, yaitu dengan cara: Perbaikan struktur dan warna gigi dan Merapatkan gigi incisivus pada kasus diastema. Sementara Keuntungan dari labial veneer, yaitu: Preparasi struktur gigi sedikit, Mempertahankan struktur gigi dan melindungi pulpa, Memiliki estetik yang sangat baik, Daya tahan terhadap abrasi 
baik, Tidak menyebabkan perubahan kontak oklusal, Preparasi gigi mudah dan Waktu kunjungan terbatas. Sedangkan Kerugian pemakaian labial veneer, adalah: Prosedur bonding rumit, Mudah terjadi overcontoured dan Sulit untuk dilepaskan. (6)

Macam-macam labial veneer : A). Partial veneer (direct partial veneer), yaitu Kerusakan kecil pada gigi vital dan teknik ini dapat dilakukan langsung pada pasien dalam satu kunjungan dengan menggunakan bahan komposit. B). Full veneer (direct full veneer) dengan bahan komposit dapat dilakukan dengan teknik langsung ataupun tidak langsung. Peletakan komposit dengan teknik langsung membutuhkan waktu dan perawatan intensif. C). Indirect yang merupakan tekhnik secara tidak langsung yang dikerjakan di laboratorium, tujuan dari teknik ini adalah memaksimalkan estetik pasien berdasarkan bahan pembuatannya. Keuntungan dari teknik tidak langsung ini yaitu memiliki anatomi yang akurat, permukaan gigi tiruan lebih halus, estetik sangat baik, kekuatan yang baik, tahan lama, dan sedikit finishing (8)

Labial veneer berdasarkan bahan, terdiri dari : a). Komposit resin, yaitu bahan ini memiliki keuntungan untuk memperbaiki estetik dengan segera, kunjungan dilakukan satu sampai dua kali, dan harganya pun terjangkau. Tetapi, mengingat bahwa bahan ini tidak bertahan lama dan harus diganti beberapa kali,

biayanya akan lebih mahal dalam jangka panjang. Bahan ini sulit untuk mengubah warna gigi jika terdapat kesalahan dalam prosedur, tetapi pembentukan kontur gigi mudah dilakukan untuk restorasi sedang ataupun besar dan b). Porcelain, bahan porcelain prosedur ini meminimalkan keterbatasan pulpa dan jaringan periodontal karena gigi yang sudah dipreparasi hampir membatasi enamel dan bergantung pada margin supragingival. Panduan anterior telah disiapkan kompatibilitas, stabilisasi warna dan translusensi yang sangat baik dan juga tahan lama. Hasil estetik bergantung pada seni dari tekhniker itu sendiri. (9)

\section{All Porcelain E-max Press.}

All porcelain E-max press adalah bahan porcelain yang berupa ingot lithium disilicate glass-ceramic highly aesthetic, memberikan homogenitas yang optimal dan memiliki kekuatan yang tinggi untuk pembuatan restorasi cekat yang akurat. Untuk alasan estetika, maka teknik pembuatan dan indikasi dapat direkomendasi untuk setiap ingot pada tingkat translusensi. (5)

Macam-macam all porcelain E-max press, terdiri dari E-max press polychromatic yang merupakan salah satu bahan ingot yang memiliki gradasi warna tersendiri dalam satu ingot. dan E-max press monochromatic yang tersedia dalam 2 ukuran dan 5 level translusensi yang berbeda, yaitu: HT (high translucency), MT (medium translucency), LT (low translucency), MO (medium opacity), HO (high opacity). (10).

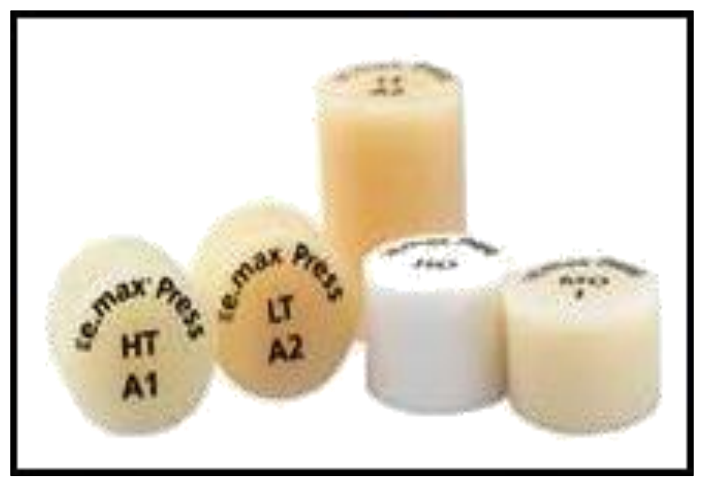

Gambar 3. Ingot E-max Press 


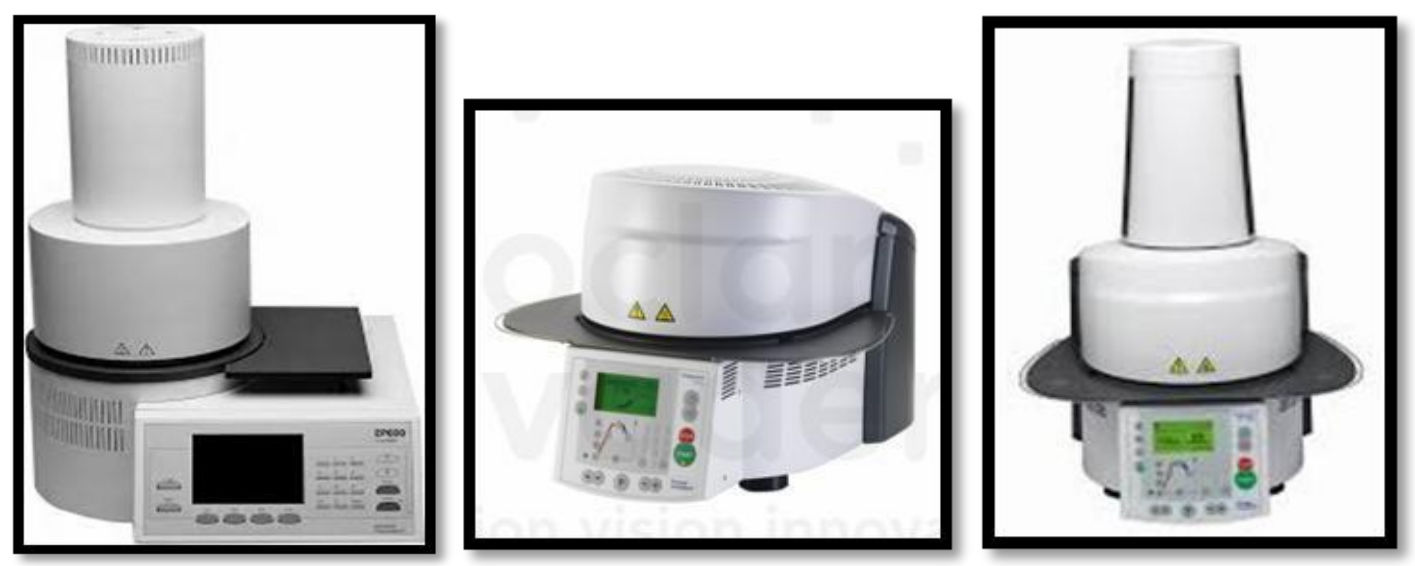

Gambar 4. Alat Programat

Alat yang digunaan dalam pembutan labial veneer all porcelain dengan metode press dapat dilakukan dengan beberapa macam alat, antara lain yaitu menggunakan alat Programat EP 600 adalah salah satu jenis mesin yang dirancang untuk menekan (press) ingot IPS E-max press serta pembakaran (firing) dental ceramics materials dan hanya boleh digunakan untuk tujuan tersebut saja. (11)

Indikasi dalam pemakaian bahan all pocelain E-max press, yaitu: Labial veneer, Oklusal veneer, Inlay, Onlay, Partial crown, Crown pada anterior dan posterior dan bridge anterior 3 unit. (5) Ditunjukkan Gambar 3 dan 4.

\section{METODE KERJA}

Pembuatan pembuatan labial veneer all porcelain dengan metode press untuk memperbaiki estetik pada pasien dengan kasus diastema sentral terdiri dari pembuatan lapisan dasar menggunakan Metode Press dan Build-up porcelain.

\section{Pembuatan lapisan dasar menggunakan Metode Pres}

Tahap yang dilakukan dalam pembuatan lapisan dasar ini, (Gambar 5 dan 6) yaitu: 1). Penerimaan Studi Model; 2). Persiapan model kerja; 3). Pembuatan die dengan pindex system untuk dibuatkat tempat pin ;

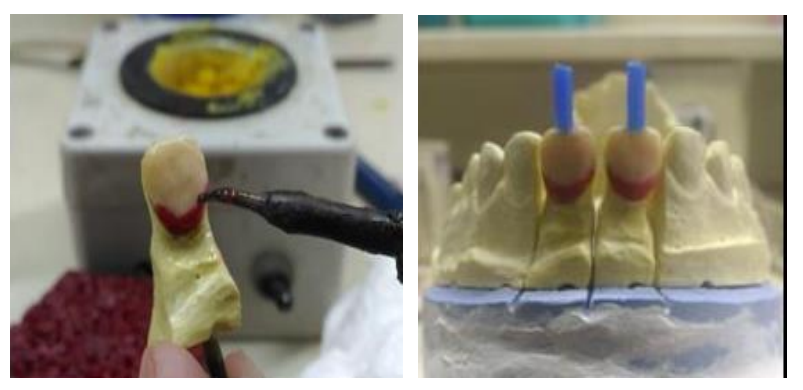

Gambar 5. Wax up dan spruing

4). Wax Contouring (wax up) untuk lapisan dasar menggunakan tiga jenis wax yaitu, lapisan pertama menggunakan wax kuning (dipping wax) sebagai lapisan dasar dengan cara dicelupkan sebanyak satu kali, kemudian dilakukan pengambilan pada 
bagian wax melebihi batas preparasi. Lapisan kedua menggunakan servical wax pada bagian servical dengan cara di ulasi dan yang ketiga menggunakan wax organik dengan cara mengulasi pada seluruh permukaan labial atau bagian body dengan ketebalan minimum 0,5-0,8mm.; 5). Spruing, yaitu pemasangan sprue pada pola malam yang telah selesai dibuat; 6). Investing; 7). Preheating 8). Pressing, dengan cara IPS e-max plunger dan ingot emax diberi separator (alox plunger separator) berupa powder agar pada saat divesting ingot tidak menempel pada plunger. Kemudian investment ring dikeluarkan dari preheating furnice untuk melakukan proses pressing. Selanjutnya menyalakan mesin furnace EP 3000 dengan menekan tombol berwana hitam yang terdapat di belakang mesin, lalu Ingot dimasukkan ke dalam mould speace investment ring yang sudah dilakukan preheating dan meletakkan alox plunger diatas ingot pada mould speace, kemudian dilakukan pressing dengan menggunakan alat Programat EP 3000.; 9). Divesting ; 10). Cutting sprue.
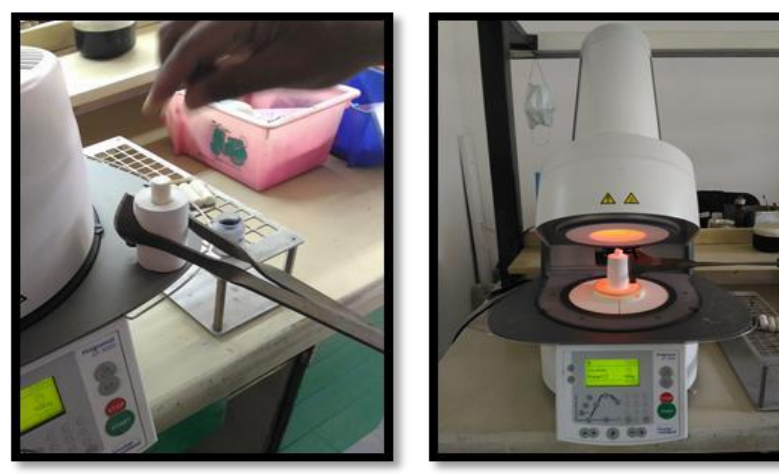

Gambar 6. Pressing lapisan dasar

\section{Build-up porcelain}

Build up Porcelain (Gambar 7) terdiri dari prosedur. Foundation firing, yaitu Lapisan dasar labial veneer dilapisi dengan selapis tipis liquid ceramic pada lapisan dasar labial veneer dan menaburkan powder foudation ceramic di atas permukaan liquid menggunakan kuas dan arteri clamp, kemudian dilakukan kondensasi dengan cara digetarkan. Selanjutnya dilakukan pembakaran (firing) dengan menggunakan alat P 300 pada suhu $750^{\circ} \mathrm{C}$; 2). Aplikasi dentin dan incisal, yaitu Powder dentin dan liquid ceramic diaduk di atas glass plate, kemudian diaplikasikan menggunakan kuas pada permukaan lapisan dasar labial veneer yang sudah dilakukan pembarakaran (firing)
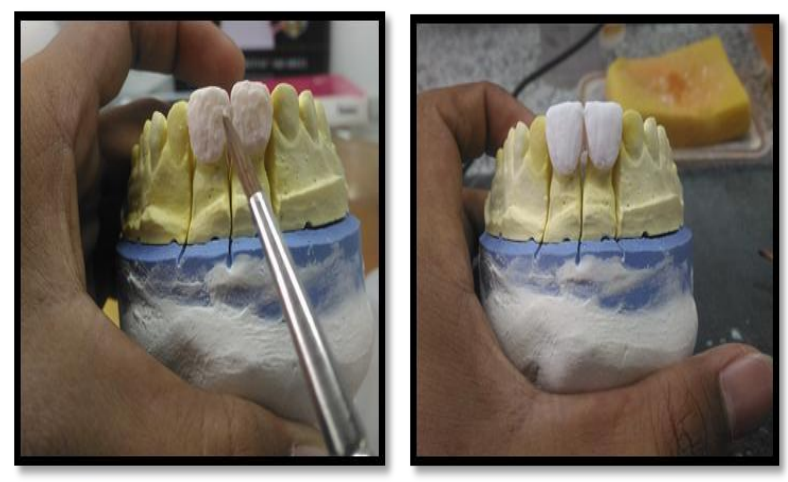

\section{Gambar 7. Build up porcelain}

bubuk foundation ceramic. Diratakan pada seluruh permukaan labial tetapi ditipiskan pada bagian incisal, kemudian pada permkuaan incisal di aplikasikan incisal ceramic lalu diratakan dan dibentuk sesuai anatomi serta dilakukan kondesasi dengan menggetarkan model dan air diserap menggunakan tissue.; 3). Aplikasi stain dan glaze pada bagian cervical diaplikasikan dengan pasta stain.

\section{HASIL DAN PEMBAHASAN}

Hasil dari pembuatan yang diperoleh setelah selesai pembuatan labial veneer all porcelain sebagai berikut : 1). Diastema 
central tertutup rapat sehingga membentuk kontak bidang dengan gigi sebelahnya; 2). Permukaan labial terlihat seperti gigi asli: 3). Tepi labial veneer kontak rapat dengan tepi gigi yang di preparasi : 4). Permukaan halus dan mengkilap; 6).Estetik baik . Tampak hasil dari proses ditunjukkan pada Gambar 8.

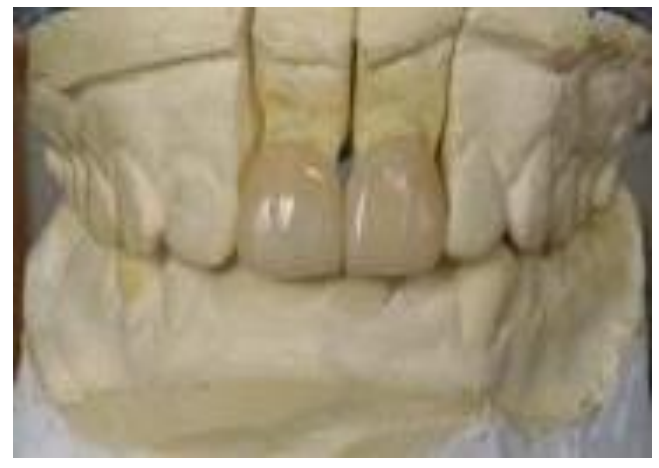

Gambar 8. Hasil

Diastema sentral merupakan suatu keadaan dimana terdapat diastema pada gigi tengah rahang atas diantara gigi incisivus satu kanan dan kiri. Kasus ini banyak terjadi pada masyarakat sehingga menimbulkan keluhan rasa tidak percaya diri. Kasus ini dapat diperbaiki dengan beberapa cara, salah satunya adalah dengan pembuatan restorasi labial veneer. Pada kasus diastema sentral dipilih dengan alasan preparasi yang dilakukan relatif lebih sedikit dibandingkan dengan pembuatan mahkota. Preparasi hanya dilakukan pada permukaan labial gigi incisivus saja, berbeda dengan restorasi jacket crown preparasinya dilakukan pada seluruh permukaan gigi serta waktu preparasi yang lama dan sulit sehingga resiko merusak jaringan gigi akan lebih besar. $(6,12)$

Ada beberapa jenis bahan yang dapat digunakan untuk pembuatan restorasi labial veneer, diantaranya bahan yang digunakan adalah all porcelain e-max press. Warna yang dihasilkan dari bahan all porcelain $e$ max press dapat disesuaikan dengan gigi asli. Bahan ini terdiri dari dua jenis ingot yaitu polychromatic ingot dan monochromatic ingot. Dengan metode press, menggunakan alat pressing dan firing (furnace). Metode yang digunakan di sini menggunakan monochromatic ingot, yaitu dengan cara melakukan pembuatan lapisan dasar labial veneer kemudian mengaplikasikan dental ceramic yaitu dentin dan incisal. Pekerjaan ini lebih lama dibandingkan menggunakan polychromatic ingot (multi layered), karena bahan polychromatic ingot sudah tersedia warna yang sesuai dengan warna gigi dalam ingot tersebut dan dalam satu kali pressing serta satu kali firing.

Pada saat pembuatan die menggunakan alat pindex system, karena dengan menggunakan alat pindex system ini lebih mudah dan tidak memerlukan locktry.

Die ini berfungsi untuk mempermudah pada saat aplikasi. Pada saat melakukan tahap wax contouring (wax up) penulis menggunakan tiga jenis wax, akan tetapi pada bagian body menggunakan wax organik, berbeda pengan pedoman pembuatannya, karena inlay wax tidak tersedia dilaboratorium. Wax organik ini mempunyai sifat kegunaan yang sama dengan inlay wax.

Ring yang digunakan Pada saat investing yaitu menggunakan silicon ring. Penggunaaan ring dengan bahan silicon ring ini berguna untuk mempermudah saat membuka investment ring dan untuk menghindari pemuaian bahan investment pada saat setting time. Pada proses pressing menggunakan alox plunger diatas ingot pada mould speace. Alat ini berfungsi untuk menekan atau mengepress ingot agar ingot mengalir pada mould speace. Setelah 
dilakukan pressing, investment ring didinginkan hingga mengalami keretakan. Kemudian investment ring diukur dengan menggunakan alox plunger untuk dijadikan panduan antara batas bahan pressing dengan alox plunger dan dipotong serta dilakukan sanblasting untuk untuk memisahkan hasil pressing dengan investment ring. Setelah melakukan sanblasting seharusnya dilakukan penblasting untuk menambah retensi pada lapisan dasar labial veneer, akan tetapi pada prosedur ini penulis tidak melakukan dikarenakan mengikuti prosedur di laboratorium.

Pada tahap awal aplikasi dental ceramic dilakukan fondation firing terlebih dahulu mengaplikasikan selapis tipis liquid kemudian ditaburkan powder foundation ceramic pada permukaan lapisan dasar labial veneer. Kegunaan foundation firing ini untuk mendapatkan retensi agar perlekatan antara lapisan dasar labial veneer dengan dental ceramic melekat dengan baik. Kemudian dilakukan aplikasi dentin ceramic diatas permukaan foundation ceramic yang sudah dilakukan pembakaran dan dilanjutkan dengan aplikasi incisal ceramic diatas permukaan dentin.

\section{SIMPULAN DAN SARAN}

Pembuatan Labial veneer all porcelain dengan metode press mempunyai keuntungan memberikan homogenitas yang optimal dan memiliki kekuatan yang tinggi untuk pembuatan restorasi cekat yang akurat, karena terlebih dahulu dilakukan pembuatan lapisan dasar yang disesuaikan dengan kasus diastema sentral dan melakukan aplikasi dentin dan incisal untuk mendapatkan warna yang sesuai dengan gigi asli. Dalam pembuatannya perlu diperhatikan beberapa hal, antara lain adalah ketrampilan tekniker dalam melakukan wax up yang disesuaikan dengan ketebalan labiopalatal gigi, kontak proksimal area diastem dan lengkung gigi. Untuk mendapatkan restorasi yang baik diperlukan hubungan kerja sama yang baik antara dokter gigi dan teknisi gigi sehingga diperoleh labial veneer dengan estetik yang baik.

\section{DAFTAR PUSTAKA}

1. Joneja $\mathrm{P}, \mathrm{dkk}$. Factors To Be Considered in The Treatment of Midline Diastema. International Journal of Current Pharmaceutical Research. Vol 5 (2). 2013. Hal: 1.

2. Sutjiati Rina. Penata Laksanaan Penutupan Diastema Sentral SetelahPencabutan Gigi Mesiodens. Bagian Ortodonsia Fakultas Kedokteran Gigi Universitas Jember. Indonesia. Stomatognatic (J.K.G. Unej) Vol. 8 No. 12011 : 56-61.

3. Bashi E, dkk. A Composite Laminate Veneer Technique for DiastemaClosure : A Report of Ten Cases. International Dental Research. Volume 2, 2013. Hal: 67.

4. Solanki Gaurav. Porcelain Laminate Veneer on A Higly Discolored Tooth: A Case Report. International Journal of Biomedial Research. 2013. Hal: 412.

5. http://www.ivoclarvivadent.uszooluweb site mediadocument1265IPS+emaxPress.pdf (Diunduh pada tanggal 23 Oktober 2015, 14:41 WIB)

6. Haga Mechio dan Nakazawa Akira. Vinir Porselen Laminasi. Hipokrates. Jakarta, 1995. Hal: 1-2.

7. Walmsley AD, Walsh TF, Lumley PJ, dkk. Restorative Dentistry. Churchill Livingstone Elsevier. United Kingdom, 2007. Hal: 129-130. 
8. Kumar N, Srivastava S, dkk. Veneer in Restorative Dentistry. Asian Journal of Oral Health Sciences. Volume 2, Issue 2, 2012. Hal: 19-20.

9. Chiche Gerard and Pinault Alain. Esthetics of Anterior Fixed Prosthodontics. Quintessence Books. Singapore, 1994. Hal: 42.

10. http://www.maxrevolution.com/assets/ ifu-emax-press_english.pdf (Diunduh pada tanggal 20 November 2015, 18:14 WIB).

11. www.ivoclarvivadent.us/zooluwebsite/ media/document/6033/EP+600+Combi. (Diunduh pada tanggal 15 Desember 2015, 13:54 WIB)/

12. https://www.google.co.id/webhp?source $\mathrm{id}=$ chromeinstant $\&$ ion $=1 \&$ espv $=2 \&$ ie $=$ UTF8\#q=programat \%20p $\% 20300$ (Diunduh pada tanggal 17 Juni 2016, 09:04 WIB). 